\title{
Gugatan Pelanggaran Asas-Asas Umum Pemerintahan yang Baik Setelah Berlakunya UU Administrasi Pemerintahan melalui PTUN Yogyakarta
}

\author{
Eny Kusdarini \\ Jurusan PKn dan Hukum FIS UNY \\ eny_kusdarini@uny.ac.id
}

\begin{abstract}
An unfair administrative decision considering by individuals or private corporates subject to be dismissed through Public Administrative Courts. This essay was written based on research conducted during September 2016 on the final and executable judge's decision after issuing Governmental Administration Law regulating the good government principles. This research was conducted by identifying the final and executable judge's decision after issuing Governmental Administration Law at Public Administration Court on October 2016. Considering that based on this law, article 10 verse (1) contains the Good Governance Principles, namely: certainty due to law, utility, impartial, thoughtful, non-abuse principle, transparency, public interest first, and public service were applied as long as considered by judge expressed on the final and executable judge's decision. Therefore, hopefully after the enactment of the law judge on Public Administrative Court should apply these principles on judicial practices. Hopefully, this essay can be considered as an input to revise the law as well as additional materials teaching on good governance among University Lecturer.

Keywords: good government principles governmental, administration law, public administration court.
\end{abstract}

\section{Pendahuluan}

Pengadilan Tata Usaha Negara (PTUN) Yogyakarta merupakan salah satu lembaga peradilan administrasi negara tingkat pertama yang ada di wilayah di Daerah Istimewa Yogyakarta yang berkedudukan di Yogyakarta. Pada saat ini PTUN Yogyakarta merupakan satu-satunya peradilan tata usaha negara tingkat pertama yang ada di Daerah Istimewa Yogyakarta. Oleh karena itu apabila ada seseorang atau badan hukum perdata yang merasa kepentingannya dirugikan akibat dikeluarkannya sebuah keputusan atau tidak dikeluarkannya sebuah keputusan yang dimohon oleh seseorang atau badan hukum perdata pada alat administrasi negara atau pejabat administrasi negara di lingkungan Daerah Istimewa Yogyakarta dan sekitarnya dapat mengajukan gugatannya melalui PTUN Yogyakarta. Berkaitan dengan sangkaan pelanggaran terhadap asas-asas umum pemerintahan yang baik yang dilakukan oleh alat administrasi negara atau birokrat yang merugikan seseorang atau badan hukum perdata di lingkungan DIY dan sekitarnya, maka mereka dapat mengajukan gugatan ke PTUN Yogyakarta.

Gugatan seseorang atau badan hukum perdata ini akan dinilai oleh hakim berdasarkan peraturan perundangan yang berlaku. Pada tahun 2014 pemerintah Indonesia mengeluarkan Undang-Undang Nomor 30 tahun 2014 tentang Administrasi Pemerintahan atau sering dikenal dengan nama Undang-Undang Administrasi Pemerintahan. Undang-undang tersebut secara formal mengakui keberadaan asas-asas umum pemerintahan yang baik di dalam penyelenggaraan pemerintahan di Indonesia. Asas-asas ini harus dipatuhi oleh para birokrat dalam menyelenggarakan pemerintahan baik di pusat maupun di daerah supaya yang dilakukannya tidak merugikan masyarakat yang akhirnya bisa digugat melalui PTUN. Berdasarkan ketentuan pasal 53 ayat (2) Undang-undang Peradilan Tata Usaha Negara 
pelanggaran terhadap asas-asas umum pemerintahan yang baik dapat digugat melalui PTUN. Berdasarkan Pasal 53 ayat (2) Undang-undang Peradilan Tata Usaha Negara tersebut beserta penjelasannya, alasan-alasan pengajuan gugatan ke peradilan tata usaha negara mengenai pelanggaran asas-asas umum pemerintahan yang baik sekaligus dipakai sebagai dasar pengujian oleh hakim untuk memutuskan sengketa tata usaha negara. Untuk itu perlu diidentifikasi putusan hakim terhadap pelanggaran asas-asas umum pemerintahan yang baik di PTUN Yogyakarta setelah berlakunya Undang-Undang Administrasi Pemerintahan.

Adapun rumusan masalah yang diangkat dalam penelitian ini yakni bagaimanakah:

1. Kasus-kasus gugatan terhadap pelanggaran asas-asas umum pemerintahan yang baik apa sajakah yang telah diputuskan oleh hakim PTUN Yogyakarta setelah berlakunya UndangUndang Administrasi Pemerintahan;

2. Putusan hakim PTUN Yogyakarta terhadap gugatan penggugat setelah berlakunya UU Administrasi Pemerintahan.

Tujuan yang ingin dicapai dalam penelitian ini adalah untuk mengidentifikasi dan menganalisis kasus-kasus gugatan terhadap asas-asas umum pemerintahan yang baik dan putusan hakim PTUN Yogyakarta setelah berlakunya Undang-undang Administrasi Pemerintahan.

Untuk mengkaji putusan hakim PTUN Yogyakarta setelah berlakunya UU Administrasi Pemerintahan diadakan beberapa kajian mengenai konsep subjek Hukum Administrasi Negara, Penggugat dan Tergugat dalam Peradilan Tata Usaha Negara, asas-asas umum pemerintahan yang baik, kewenangan absolut Peradilan Tata Usaha
Negara, dan sengketa tata usaha negara. Salah satu subjek hukum dalam Hukum Administrasi Negara adalah para birokrat yang sering disebut alat administrasi. Sebagai subjek hukum di dalam HAN, para birokrat ini mempunyai tugas dan wewenang untuk menyelenggarakan kepentingan umum. Di dalam melakukan tindakan untuk menyelenggarakan kepentingan umum mereka harus mengindahkan asas-asas yang berlaku di dalam HAN. Asas-asas ini sering dikenal dengan sebutan asas-asas umum pemerintah yang baik, yang pada tahun 2014 telah dituangkan secara formal dalam UU No 30 Tahun 2014 tentang Administrasi Pemerintahan. Tindakan para birokrat yang didasarkan pada asas-asas umum pemerintahan yang baik ini dalam lapangan HAN sangat diperlukan, mengingat kekuasaan negara mempunyai wewenang yang istimewa di dalam rangka penyelenggaraan kesejahteraan dan kepentingan umum sangat luas. Apalagi Indonesia sebagai negara hukum yang berorientasi pada negara kesejahteraan (welfare state), intensitas campur tangan negara dalam kehidupan masyarakat semakin berkembang, sehingga peranan HAN semakin dominan dan penting.

Para pihak dalam peradilan tata usaha negara adalah:

1. Penggugat dalam hal ini adalah seseorang atau badan hukum perdata yang merasa kepentingannya dirugikan akibat dikeluarkannya Keputusan Tata Usaha Negara oleh badan atau Pejabat Tata Usaha Negara (Pasal 53 ayat (1) UU No 5 Tahun 1986 tentang Peradilan Tata Usaha Negara);

2. Tergugat adalah Badan atau Pejabat Tata Usaha Negara yang mengeluarkan keputusan berdasarkan wewenang yang 
ada padanya atau yang dilimpahkan kepadanya, yang digugat oleh seseorang atau badan hukum perdata (Pasal 1 angka 6 UU No 5 Tahun 1986 tentang Peradilan Tata Usaha Negara).

Adapun alasan-alasan untuk pengajuan gugatan ke PTUN diantaranya adalah bahwa keputusan yang digugat di samping bertentangan dengan peraturan perundangundangan yang berlaku juga bertentangan dengan asas-asas umum pemerintahan yang baik. Sebagian asas-asas umum pemerintahan yang baik ini sudah dituangkan dalam berbagai peraturan perundang-undangan. Namun demikian sebagian dari asas-asas ini merupakan bagian dari Hukum Administrasi Negara tidak tertulis. Di Indonesia teori mengenai asas-asas umum pemerintahan yang baik telah dikembangkan oleh Purbopranoto (1978) yang terdiri dari 13 asas, yakni :

1. kepastian hukum (principle of legal security);

2. keseimbangan

(principle

of proportionality);

3. kesamaan dalam mengambil keputusan (principle of equality);

4. bertindak cermat (principle of carefulness);

5. motivasi untuk setiap keputusan (principle of motivation);

6. jangan mencampuradukkan kewenangan (principle of non-misuse of competence);

7. permainan yang layak (principle of fair play);

8. keadilan atau kewajaran (principle of reasonableness or prohibition of arbitrariness);

9. menanggapi pengharapan yang wajar (principle of meeting raised expectation); 10. meniadakan akibat-akibat suatu keputusan yang batal (principle of undoing the consequences of annulled decision);

11. perlindungan atas pandangan hidup (principle of protecting the personal way of life);

12. kebijaksanaan (saphientia);

13. penyelenggaraan kepentingan umum (principle of public servis).

Asas-asas tersebut berpangkal tolak dari teori-teori hukum dan yurisprudensi serta norma- norma yang hidup dalam masyarakat. Untuk itu berlakunya asas-asas ini di Indonesia harus disesuaikan dengan falsafah Pancasila dan UUD 1945, dan juga tampaknya UU Peradilan Tata Usaha Negara sudah mengakuinya dengan mencantumkan dalam rumusan ketentuan pasal 53 ayat 2 UU Peradilan Tata Usaha Negara beserta penjelasannya yakni mengenai alasan-alasan pengajuan gugatan ke peradilan tata usaha negara yang sekaligus dipakai sebagai dasar pengujian oleh hakim untuk memutuskan sengketa administrasi negara dengan warga masyarakat atau badan hukum perdata. Alasan-alasan untuk mengajukan gugatan ke Peradilan Tata Usaha Negara tersebut berdasarkan ketentuan Pasal 53 ayat (2) UU Peradilan Tata Usaha Negara yakni bahwa keputusan tata usaha yang digugat itu melanggar peraturan perundang-undangan yang berlaku dan melanggar asas-asas umu pemerintahan yang baik. Namun demikian berdasarkan ketentuan UU Peradilan Tata Usaha Negara yang dimaksud dengan asasasas umum pemerintahan yang baik masih mengacu pada ketentuan UU mengenai Penyelenggaraan Negara yang Bersih dan Bebas dari KKN.

Pada tahun 2014 Pemerintah Republik Indonesia mengeluarkan Undang-undang Nomor 30 Tahun 2014 tentang Administrasi Pemerintahan. Berdasarkan ketentuan Pasal 5 
Undang-Undang Nomor 30 Tahun 2014, dinyatakan bahwa penyelenggaraan administrasi pemerintahan (di Indonesia) diselenggarakan berdasarkan: asas legalitas, asas perlindungan terhadap Hak Asasi Manusia, dan Asas-Asas Umum Pemerintahan yang Baik (AUPB). Adapun asas-asas umum pemerintahan yang baik (AUPB) yang dimaksud dalam undangundang ini berdasarkan ketentuan Pasal 10 ayat (1) adalah meliputi asas: kepastian hukum, kemanfaatan, Ketidakberpihakan, kecermatan, tidak menyalahgunakan kewenangan, keterbukaan, kepentingan umum, dan pelayanan yang baik. Sedangkan asas-asas umum lainnya di luar AUPB sebagaimana dimaksud pada Pasal 10 ayat (1) dapat diterapkan sepanjang dijadikan dasar penilaian hakim yang tertuang dalam putusan Pengadilan yang berkekuatan hukum tetap.

Adapun dasar gugatan untuk mengajukan gugatan sengketa tata usaha negara yang sekaligus dipakai sebagai dasar pengujian hakim dalam memeriksa, menilai memberikan putusan diatur dalam ketentuan Pasal 53 ayat 2 UU No. 5 Tahun 1986 tentang Peradilan Tata Usaha Negara sebagaimana telah diperbaiki dengan UU No. 9 Tahun 2004 tentang Perubahan Atas UU No. 5 Tahun 1986 tentang Peradilan Tata Usaha Negara yang telah diperbaiki lagi dengan UU No. 51 Tahun 2009 tentang Perubahan Kedua Atas UU No. 5 Tahun 1986 tentang Peradilan Tata Usaha Negara.

Pelanggaran terhadap asas-asas umum pemerintahan yang baik oleh alat administrasi negara dalam pembuatan dan pengeluaran keputusan administrasi negara berdasarkan ketentuan Pasal 53 ayat 2 UU Peradilan Tata Usaha Negara dapat dipakai alasan untuk mengajukan gugatan ke peradilan tata usaha negara (Wiyono, 2005, pp. 76-77). Di samping sebagai alasan untuk mengajukan gugatan ke Peradilan Tata Usaha Negara juga dapat dipakai sebagai dasar pengujian oleh hakim terhadap tindakan yang dilakukan oleh alat administrasi negara. Ketentuan Pasal 53 UU No. 9 Tahun 2004 tentang Perubahan Atas UU No. 5 Tahun 1986 tentang Peradilan Tata Usaha Negara menyatakan bahwa:

(1) Orang atau badan hukum perdata yang merasa kepentingannya dirugikan oleh suatu Keputusan Tata Usaha Negara dapat mengajukan gugatan tertulis kepada pengadilan yang berwenang yang berisi tuntutan agar Keputusan Tata Usaha Negara yang disengketakan itu dinyatakan batal atau tidak sah disertai tuntutan ganti rugi dan/atau rehabilitasi;

(2) Alasan-alasan yang dapat digunakan dalam mengajukan gugatan sebagaimana dimaksud pada ayat (1) adalah:

a. Keputusan Tata Usaha Negara yang digugat itu bertentangan dengan peraturan perundang-undangan yang berlaku;

b. Keputusan Tata Usaha Negara yang digugat itu bertentangan dengan asasasas umum pemerintahan yang baik.

Berdasarkan penjelasan ketentuan Pasal 53 ayat (2) huruf b UU No. 9 Tahun 2004 tersebut dinyatakan bahwa yang dimaksud dengan asas-asas umum pemerintahan yang baik adalah meliputi asas: kepastian hukum; tertib penyelenggaraan negara; keterbukaan; proporsionalitas; profesionalitas; akuntabilitas, sebagaimana dimaksud dalam UU No. 28 Tahun 1999 tentang Penyelenggaraan Negara yang Bersih dan Bebas dari Korupsi, Kolusi, dan Nepotisme. Adanya gugatan terkait dengan pelanggaran asas-asas umum pemerintahan yang baik ini 
biasanya berhubungan juga dengan diskresi yang dipunyai oleh alat administrasi negara yang sering dikenal dengan ermessen (asas bertindak atas inisiatif sendiri) yang dimungkinkan oleh hukum, untuk menyelesaikan persoalan-persoalan penting yang mendesak yang muncul, yang pengaturannya belum ada atau kewenangannya yang tidak jelas atau samarsamar. Yang harus bisa dipertanggungjawabkan secara hukum dan moral (Marbun, 2003, pp. 138-139).

Metode

Penelitian ini termasuk dalam penelitian hukum dengan pendekatan perundangundangan dan pendekatan kasus yang mengkaji dan menganalisis berbagai kasuskasus sengketa tata usaha negara dan putusan hakim PTUN dan lokasi penelitian adalah PTUN Yogyakarta. Objek penelitian adalah gugatan penggugat dan putusan hakim dalam sengketa tata usaha yang dijatuhkan setelah berlakunya Undang-Undang Administrasi Pemerintahan.

Pengumpulan data dilakukan dengan teknik wawancara yakni dengan mewawancarai hakim PTUN Yogyakarta yang telah memutuskan sengketa tata usaha negara setelah berlakunya Undang-Undang Administrasi Pemerintahan. Di samping itu untuk menjawab rumusan masalah yang diajukan juga diadakan dokumentasi terhadap putusan-putusan hakim yang telah inkrah setelah berlakunya Undang-Undang Administrasi Pemerintahan. Analisis data dilakukan melaui tahap-tahap reduksi data, unitisasi dan kategorisasi data serta penafsiran data yang telah dikumpulkan.

Hasil dan Pembahasan
Kasus-kasus Gugatan terhadap
Pelanggaran AUPB yang Telah Diputus oleh Hakim PTUN Yogyakarta Setelah

\section{Berlakunya \\ UU \\ Administrasi \\ Pemerintahan}

PTUN Yogyakarta merupakan salah satu lembaga peradilan administrasi negara tingkat pertama yang ada di wilayah di Daerah Istimewa Yogyakarta yang berkedudukan di Yogyakarta. Pada saat ini PTUN Yogyakarta merupakan satu-satunya peradilan tata usaha negara tingkat pertama yang ada di Daerah Istimewa Yogyakarta. Oleh karena itu apabila ada seseorang atau badan hukum perdata yang merasa kepentingannya dirugikan akibat dikeluarkannya sebuah keputusan atau tidak dikeluarkannya sebuah keputusan yang dimohon oleh seseorang atau badan hukum perdata pada alat administrasi negara atau pejabat administrasi negara di lingkungan Daerah Istimewa Yogyakarta dan sekitarnya dapat mengajukan gugatannya melalui PTUN Yogyakarta. Berkaitan dengan sangkaan pelanggaran terhadap asas-asas umum pemerintahan yang baik yang dilakukan oleh alat administrasi negara atau birokrat yang merugikan seseorang atau badan hukum perdata di lingkungan DIY dan sekitarnya, maka mereka dapat mengajukan gugatan ke PTUN Yogyakarta. Gugatan seseorang atau badan hukum perdata ini akan dinilai oleh hakim berdasarkan peraturan perundangan yang berlaku.

Berdasarkan analisis hasil penelitian didapatkan lima gugatan penggugat yang telah diputus oleh hakim PTUN Yogyakarta. Adapun kasus posisi dari ke lima gugatan sengketa tata usaha negara tersebut adalah sebagai berikut:

\section{Sengketa antara PT Pertamina Training and Consulting Jakarta melawan Pegawai Pengawas Ketenagakerjaan Dinas Tenaga Kerja dan Transmigrasi Kabupaten Bantul \\ Penggugat dalam surat gugatannya tanggal 20 Juni 2014 mengajukan gugatan}


yang didaftarkan di Kepaniteraan PTUN Yogyakarta dengan No. Register Perkara: 08/G/2014/PTUN.YK mengajukan dalil-dalil sebagai berikut:

- Objek gugatan adalah: Surat No. 568/660 tanggal 25 Maret 2014 yang diterbitkan oleh Pegawai Pengawas Ketenagakerjaan Disnakertrans Kabupaten Bantul, Daerah Istimewa Yogyakarta tentang Penetapan Upah Lembur AMT 1 dan AMT 2 Karyawan PT Pertamina Training Counsulting (PTC) TBBM Rewulu.

- Penggugat mengajukan gugatan ke PTUN Yogyakarta sesuai dengan waktu sebagaimana tenggang waktu untuk mengajukan gugatan yang dimaksud dalam ketentuan Pasal 55 UU No 5 Tahun 1986 tentang Peradilan Tata usaha Negara, dengan uraian sebagai berikut:

a. Pada tanggal 25 Maret 2014 tergugat menerbitkan Surat Penetapan No. 568/660, Perihal Penetapan AMT 1 dan AMT 2 Karyawan PT. Pertamina Training Consulting (PT. PTC) TBBM Rewulu;

b. Bahwa penggugat mengetahui dan menerima surat penetapan tersebut dari tergugat tanggal 10 April 2014;

c. Bahwa terhitung sejak diterimanya surat penetapan dari tergugat tersebut, tanggal 10 April 2014, kemudian penggugat mengajukan surat gugatan ke PTUN Yogyakarta tanggal 20 Juni 2014. Dengan demikian gugatan a quo masih berada dalam tenggang waktu sembilan puluh (90) hari sesuai dengan ketentuan yang telah ditentukan dalam Pasal 55 UU No 5 Tahun 1986 tentang Peradilan Tata Usaha Negara.
Adapun dasar gugatan yang diajukan oleh penggugat dalam mengajukan gugatan adalah sebagai berikut:

a. Bahwa penggugat (PT. Pertamina Training \& Consulting) adalah badan hukum yang didirikan dan berkedudukan di Jakarta Selatan dan bergerak di bidang Perusahaan Penyedia Jasa Penunjang (PPJP), salah satunya menyediakan tenaga kerja sebagai sopir Awak Mobil Tangki (AMT);

b. Bahwa antara penggugat dengan PT Pertamina Patra Niaga, telah sepakat mengadakan perjanjian kerja sama berdasarkan Surat Perjanjian No. 799/PN000.201/KTR/2012, tanggal 22 Oktober 2012 Perihal: Perjanjian Pelaksanaan Penyediaan Jasa dan Pengelolaan Awak Mobil Tangki salah satunya berada di wilayah BBM Jawa \& Madura dalam rangka menyediakan tenaga sopir pengangkut transportasi BBM ke SPBU seluruh wilayah Indonesia. Oleh karenanya karyawan penggugat telah ditempatkan bekerja di PT. Pertamina Patra Niaga sebagai sopir Awak Mobil Tangki (AMT) di daerah areal TBBM Rewulu (Jawa Tengah) tersebut;

c. Selanjutnya penggugat juga telah membuat Kesepakatan Perjanjian Kontrak Kerja dengan masing-masing para Awak Mobil Tangki (AMT). Sebagai komponen pembayaran gaji/penghasilan bulanan kepada para AMT diberikan berupa: Upah Pokok dan Upah Tunjangan Performansi. Besarnya Tunjangan Performansi dihitung berdasarkan daftar hadir masing-masing AMT dengan sistem SIOD (Sistem Informasi Operasi dan Distribusi) atau dikenal dengan istilah pembayaran upah kerajinan kerja di luar 
jam kerja, di mana standar perhitungannya berdasarkan 4 komponen/unsur, yaitu:

1) Komponen kilo liter (pengangkutan BBM dihitung berdasarkan jumlah kilo liter yang dibawa AMT);

2) Jarak kilometer;

3) Ritase (banyaknya pengantaran BBM pulang pergi ke setiap SPBUU;

4) Jumlah SPBU yang disuplai/didatangi.

Dikarenakan pekerjaan para AMT sebagai sopir jarak jauh yang memakai variabel kerja waktu jam kerja tidak tentu, jarak tempuh yang berbeda antar SPBU serta pengisian volume tangki yang harus diisi pada setiap SPBU tidak selalu sama, karenanya pendistribusian BBM tersebut harus segera dilaksanakan oleh para AMT untuk waktu yang tidak tentu tersebut;

d. Pada tanggal 21 Maret 2013 timbul permasalahan dengan laporan sebanyak lebih kurang 145 AMT secara sepihak ke Disnakertrans Kabupaten Bantul DIY (tergugat) yang melaporkan penggugat telah mempekerjakan para AMT melebihi jam kerja tanpa diberikan upah lembur sesuai dengan ketentuan Pasal 77 UU No.13 Tahun 2003 tentang Ketenagakerjaan;

e. Disnakertrans Kabupaten Bantul telah mengeluarkan Surat No. 568/660 perihal Penetapan Upah Lembur AMT 1 dan AMT 2 Karyawan PT. Pertamina Training \& Consulting (PTC) TBBM Rewulu tertanggal 25 Maret 2014. Surat tersebut menjadi objek sengketa PTUN sebagaimana dimaksud dalam ketentuan Pasal 1 angka 9 UU No 51 Tahun 2009 tentang Perubahan Kedua Atas UU No. 5
Tahun 1986 tentang Peradilan Tata Usaha Negara;

f. Tergugat secara sepihak telah mengeluarkan surat No. 568/660 tanggal 25 Maret 2014 yang pada intinya menetapkan PT. Pertamina Training \& Consulting (PTC) TBBM Rewulu harus membayar upah kerja lembur kepada lebih kurang 145 AMT tersebut, tanpa meminta lebih dulu klarifikasi pada penggugat apakah para AMT tersebut sudah mengisi Surat Perintah Kerja Lembur (SPKL);

g. Atas terbitnya surat No. 568/660 tanggal 25 Maret 2014 yang dikeluarkan oleh tergugat, kepentingan penggugat dalam melaksanakan kegiatan operasional perusahaan menjadi terganggu, karena:

1) Sebagian karyawan melakukan mogok kerja sehingga BBM yang seharusnya dapat didistribusikan ke tempat yang telah ditentukan tidak dapat dilaksanakan. Hal ini berakibat kerugian terhadap penggugat;

2) Hubungan kerja antara penggugat dengan para AMT sebagaimana telah diatur dalam perjanjian Kontrak Kerja antara penggugat dan para AMT menjadi terganggu dengan keluarnya surat No. 568/660 tanggal 25 Maret 2014 dari tergugat, yang akhirnya menjadi sengketa hukum antara penggugat dengan para karyawan (AMT) dan mengakibatkan terganggunya pula hubungan antara penggugat dengan kolega bisnis dan mencemarkan nama baik penggugat yang dianggap tidak mampu melaksanakan dan atau menangani permasalahan dengan para karyawannya yang menuntut ganti kerugian sebesar satu miliar rupiah; 
h. Tindakan tergugat mengeluarkan surat No. 568/660 tanggal 25 Maret 2014 yang menjadi objek gugatan telah melanggar hukum yang bertentangan dengan perundang-undangan yang berlaku di bidang ketenagakerjaan dan melanggar asas-asas umum pemerintahan yang baik yakni asas kepastian hukum dan asas penyalahgunaan wewenang, serta asas keadilan.

2. Sengketa antara I Nyoman Tri Santoso SIP melawan Kepala Kantor Pertanahan Kabupaten Sleman

Gugatan diajukan ke PTUN Yogyakarta pada tanggal 11 Juli 2014 dan gugatan tersebut telah diperbaiki terakhir pada tanggal 01 September 2014. Objek gugatan adalah Keputusan Tata Usaha Negara yang diterbitkan oleh Tergugat yang berupa sikap diam Tergugat terhadap surat permohonan penggugat No. Eska-26.01.14/TUN, tanggal 27 Januari 2014, perihal Pencoretan Balik Nama pada SHM No.: 6031/Wedomartani dari Atas Nama: I Nyoman Tri Santoso. Dalildalil diajukan oleh penggugat yakni bahwa:

a. Penggugat memiliki sebidang tanah berdasarkan Surat Hak Milik Atas Tanah (SHM) N. 6031/Wedomartani, Surat Ukur tanggal 06/7/2002 No.02435/2002, seluas $1.499 \mathrm{~m} 2$ terletak di Desa Wedomartani, Kecamatan Ngemplak Kabupaten Sleman atas nama I Nyoman Tri Santoso SIP;

b. Berdasarkan keputusan tergugat, hak atas tanah penggugat dialihkan haknya/dibalik nama kepada Sdr. Ikhsan dengan mendasarkan kepada Akta Jual Beli (AJB) No. 29/2010 tanggal 02 Maret 2010 yang dibuat di hadapan notaris Endang Sumarningsih, SH, M.Kn, PPAT di Sleman;

c. Oleh tergugat pada SHM tersebut dibebani hak tanggungan (HT) No. 4822/2010 Peringkat Pertama atas nama
PT BRI (Persero) TBK berkedudukan di Jakarta Pusat untuk menjamin pelunasan hutang sebesar Rp. 2.000.000.000 (dua milyar);

d. Penggugat tidak pernah menjual hak atas tanah bahkan tidak kenal Ikhsan, tidak pernah menjamin pelunasan hutang sebesar dua milyar dan tidak pernah memberikan kuasa kepada PT BRI (Persero) TBK yang berkedudukan di Jakarta sehingga kepentingan penggugat selaku pemilik hak atas tana a quo merasa dirugikan

e. Secara de facto tanah dan bangunan tersebut sejak dimiliki penggugat tahun 2008 sampai sekarang tetap dikuasai dan digunakan oleh penggugat dan keluarga, sama sekali tidak pernah beralih penguasaannya kepada Ikhsan;

f. Penggugat memohon kepada tergugat untuk mencoret balik nama/peralihan hak dari atas nama I Nyoman Tri Santosa kepada Ikhsan pada buku tanah tersebut dan mencoret penerbitan hak selanjutnya yang berupa Hak Tanggungan atas nama PT. BRI (Persero) Tbk yang berkedudukan di Jakarta Pusat, yang merupakan rangkaian tidak terpisahkan dari batalnya balik nama/peralihan hak dari atas nama I. Nyoman Santosa kepada Ikhsan tersebut;

g. Akan tetapi tergugat tidak menjawab surat permohonan penggugat atau tidak mengeluarkan keputusan sedangkan hal itu menjadi kewajibannya, maka hal tersebut disamakan dengan Keputusan Tata Usaha Negara sebagaimana diatur dalam ketentuan Pasal 3 ayat (1) UU No. 5 Tahun 1986 tentang Peradilan Tata Usaha Negara yang menyatakan bahwa: "apabila Badan atau Pejabat Tata Usaha Negara tidak mengeluarkan keputusan, 
sedangkan hal itu menjadi kewajibannya, maka hal tersebut disamakan dengan Keputusan Tata Usaha Negara”. Hal ini adalah merupakan keputusan negatif fiktif;

Oleh karena merasa kepentingannya dirugikan maka penggugat mengajukan gugatan terhadap "keputusan diam" dari tergugat Kepala Kantor Pertanahan Kabupaten Sleman atas permohonan penggugat hingga jangka waktu yang telah ditentukan dalam peraturan perundangundangan yang berlaku untuk hal tersebut telah lewat dengan tidak mengeluarkan surat keputusan tentang hal yang dimohon. Sampai jangka waktu empat (4) bulan terhitung sejak permohonan dari penggugat, tergugat bersikap diam, tidak mengeluarkan keputusan yang dimohon oleh penggugat. Sikap diam tergugat tersebut dianggap telah mengeluarkan keputusan penolakan sebagaimana diatur dalam ketentuan Pasal 3 ayat (3) UU No. 5 Tahun 1986 tentang Peradilan Tata Usaha Negara. Tindakan tergugat tersebut oleh pihak penggugat dianggap melanggar peraturan perundangundangan yang berlaku dan melanggar asasasas umum pemerintahan yang baik. Asas yang dilanggar menurut pihak penggugat terutama adalah asas kepastian hukum, proporsionalitas dan profesionalitas yang tidak diterapkan oleh tergugat secara hati-hati dalam melaksanakan kewajibannya. Menurut Penggugat tindakan tergugat Kepala Kantor Pertanahan Kabupaten Sleman merupakan tindakan cacat hukum administrasi dalam proses peralihan hak milik atas tanah dari atas nama penggugat Tri Nyoman Santosa kepada Ikhsan. Menurut penggugat tergugat telah lalai, tidak profesional dan tidak proporsional dalam melakukan apa yang seharusnya dilakukan untuk menindaklanjuti permohonan penggugat malah bersikap diam sehingga perbuatan tergugat melanggar ketentuan perundang-undangan yang berlaku dan asas-asas umum pemerintahan yang baik.

Kasus ini berkait juga dengan kasus pidana yang dilakukan oleh Sdr Ikhsan terkait dengan tindakan penipuan dan penggelapan yang dilakukan oleh Ikhsan terhadap Surat Hak Milik (SHM) atas tanah I Nyoman Santosa yang dipakai untuk meminjam uang di Bank BRI (Persero) Tbk Jakarta Pusat sebesar 2.000.000.000 (dua milyar). Oleh pihak kepolisian Ikhsan ditetapkan DPO karena melarikan diri dan tidak diketemukan. Kasus ini juga berkaitan dan kasus investasi antara sdr Ikhsan dengan istri penggugat yang berama Ny. Inana Musailimah yang rencananya bekerjasama usaha minyak goreng dari kopra di lokasi rumah I Nyoman Santosa yag kemudian sertipikatnya beralih ke Sdr Ikhsan. Kasus ini juga disidangkan di PN Sleman dengan kasus dugaan kejahatan penipuan dan atau penggelapan yang dilakukan oleh Ikhsan dan telah dilakukan pemanggilan berkali-kali serta setelah dicari di alamat rumahnya Ikhsan tidak diketemukan.

3. Sengketa antara Yundarningsih SN, SPd melawan Kepala Kantor Regional I BKN yang berkedudukan di JI Raya Magelang Km 7,5 Sleman Yogyakarta

Kasus ini merupakan kasus sengketa kepegawaian antara seorang guru SD pada SD Medalem II Dinas P dan K Ranting Menden Cabang di Daerah Blora Provinsi Jawa Tengah, yang diajukan tanggal 21 Januari 2015. Objek gugatan adalah Surat Keputusan Kepala Kantor Regional I Badan Kepegawaian Negara Nomor 000166/KEP/BV/23316 tertanggal 28 Oktober 2014 "Mengenai Pensiun Atas nama Yundarningsih, SN. SPd". Penggugat mulai bekerja pada tanggal 1 Januari 1982 di SD 
Medalem II karena ada hubungan yang tidak harmonis dengan seorang teman guru di SD tersebut akhirnya minta dipindahkan ke SD Balun VII Dinas P dan K ranting Cepu Cabang Kabupaten Blora. Di SD yang baru difitnah lagi oleh guru yang lain dan minta pindah lagi di SD yang lain. Yundarningsih ini kemudian oleh Ka Sub Dinas Pendidikan Nasional Kabupaten Blora di suruh ke RS Pati untuk diperiksa kesehatannya. Akhirnya keluarlah SK Bupati Blora No.143 Tahun 2009 yang mendasarkan diri pada Surat Keterangan Dokter RS Pati, Yundarningsih diberhentikan dari jabatan guru dan dinyatakan memenuhi syarat untuk pekerjaan tertentu sehingga kemudian berdasarkan Surat Tugas No. 824.1/237 diberi tugas baru sebagai Tenaga Administrasi pada Cabang Dinas Kecamatan Cepu sehingga dengan surat tugas tersebut Penggugat merasa direkayasa dan ditipu agar lepas dari jabatan guru.

Penggugat dalam dalil gugatannya menyatakan bahwa sampai tanggal 12 November 2014 bahkan sampai tanggal 18 Februari 2015 merasa belum pernah menerima surat pemberitahuan dari Kepala Kantor Regional I Badan Kepegawaian Negara sesuai dengan peraturan perundangundangan yang berlaku. Namun demikian pada tanggal 12

November 2014 penggugat menerima Surat Keputusan Kepala Kantor Regional I Badan Kepegawaian Negara Nomor 000166/KEP/BV/23316 tertanggal 28 Oktober 2014 mengenai pensiun atas nama dirinya. Oleh karena merasa dirugikan haknya dengan keluarnya SK Pensiun tersebut karena awalnya dia seorang guru yang mestinya pensiun pada usia 60 tahun, akan tetapi karena Penggugat diberi jabatan non guru sehingga dikeluarkan SK Pensiun usia 56 tahun. Pada hal kemudian keluar UU Aparatur Sipil Negara yang mengatur usia pensiun PNS adalah 58 tahun. Penggugat lalu menggugat SK Pensiun yang dikeluarkan oleh Kepala Kantor Regional I Badan Kepegawaian Negara ke PTUN Yogyakarta.

Alasan-alasan penggugat dalam mengajukan gugatannya:

a. Objek sengketa telah memenuhi unsur Keputusan Tata Usaha Negara sebagaimana dimaksud Pasal 1 angka 9 UU No. 51 Tahun 2009 tentang Perubahan Kedua Atas UU No. 5 Tahun 1986 tentang Peradilan Tata Usaha Negara dan merupakan kompetensi absolut dari PTUN untuk memeriksa dan mengadilinya;

b. Penggugat merasa dirugikan kepentingannya dengan keluarnya Keputusan TUN yang dikeluarkan pihak tergugat yang bersifat langsung, pribadi dan dapat ditentukan luas cakupannya yakni bahwa penggugat telah kehilangan haknya atas penerimaan gaji, tunjangan fungsional dan pendapatan lain-lain. Bahkan sejak tanggal 1 Februari 2013 sampai gugatan ini diajukan ke PTUN Yogyakarta tidak menerima gaji sama sekali;

c. Bahwa dengan dikeluarkannya Surat Keputusan Tergugat yakni Keputusan Badan Kepegawaian Negara No. 000166/KEP/BV/23316/14 tertanggal 28 Oktober 2014 oleh tergugat yang seharusnya tergugat melakukan pengawasan dan penelitian secara melekat terhadap berkas usulan pensiun penggugat yang diajukan oleh Kantor Badan Kepegawaian Daerah Kabupaten Blora. Sebagai penelaah dan penyusun bahan pemantauan dan evaluasi kelembagaan Kantor Regional I Badan Kepegawaian 
Negara Yogyakarta di Yogyakarta (tergugat) seharusnya tidak mengambil langkah-langkah sesuai kewenangannya untuk merespon positif atas telaah hukum yang penggugat sampaikan;

d. Untuk hal tersebut penggugat mohon pada PTUN Yogyakarta untuk:

1) Mengabulkan gugatan untuk seluruhnya;

2) Menyatakan batal atau tidak sah Surat Keputusan Badan Kepegawaian Negara No. 000166/KEP/BV/23316/14 tertanggal 28 Oktober 2014 mengenai pension atas nama Yundarningsih SN SPd;

3) Memerintahkan kepada tergugat untuk mencabut SK No. 000166/KEP/BV/23316/14 tertanggal 28 Oktober 2014 , dan memerintahkan tergugat untuk menerbitkan SK yang baru;

4) Memerintahkan pada tergugat untuk merehabilitasi hak-hak penggugat;

5) Menghukum tergugat untuk membayar biaya perkara yang timbul dalam perkara ini.

\section{Sengketa antara Ny. Suwalini Soegito} dkk melawan Kepala Kantor Pertanahan Kabupaten Sleman

Kasus bermula akibat dari pembagian warisan dari orang tua pihak Penggugat yang kemudian tertukar Gambar Situasinya sehingga menimbulkan percekcokan antara para penggugat dan Agus Suharmanto yang sulit untuk didamaikan ole Kepala Dukuh Kutu Patran dan tokoh masyarakat. Akhirnya para Penggugat menggugat Kepala Pertanahan Kabupaten Sleman untuk mencabut Sertifikat Hak Milik dan menerbitkan Surat Keputusan baru. Adapun dalil-dalil gugatan penggugat adalah sebagai berikut: a. Objek sengketa berupa suatu penetapan tertulis (beschkking) memenuhi ketentuan Pasal 1 angka 9 UU No. 51 Tahun 2009 tentang Perubahan Kedua Atas UU No. 5 Tahun 1986 tentang Peradilan Tata Usaha Negara;

b. Keputusan tersebut (objek sengketa) dikeluarkan oleh Badan atau Pejabat Tata Usaha Negara dalam hal ini adalah Kepala Kantor Pertanahan Sleman;

c. Para penggugat memiliki sebidang tanah dengan sertipikat hak milik atas tanah No. 1622/Desa Sinduadi, tanggal 27-8-1990 Gambar situasi tanggal 16-8-1990 No. 11.776 luas: $1.199 \mathrm{~m} 2$, terakhir atas nama Hadi Sugito diterbitkan oleh Kantor Pertanahan Kabupaten Sleman terletakdi Dusun KutuPatran RT 05/14 Sinduadi Mlati Sleman Yogyakarta dengan keterangan seluas: $1.199 \mathrm{~m} 2$. Atas hak Hadi Sugito adalah Akta Bagi Waris No. 212/WR/MLT/1989. Selanjutnya beralih kepada Para Penggugat melalui Surat Keterangan Waris tanggal 27 April 2015;

d. Bahwa dalam Akta Bagi Waris No. 212//WR/MLT/1989 menyebutkan Kariyodimejo sebagai pemilik tanah (pemilik awal) mewariskan sebidang tanah kepada Hadi Sugito seluas 1.199 m2 sebagaimana ditunjukkan dengan gambar situasi (GS) No. 6044/1989. Selanjutnya pasca meninggalnya Hadi Sugito pada tanggal 14 Desember 2012 sebagaimana tercatat pada Akta Kematian maka tanah tersebut beralih kepada para penggugat sebagaimana dijelaskan pada surat Keterangan Waris tanggal 27 April 2015;

e. Dalam penunjukan warisan yang lain Karyodimejo menyebutkan telah memberikan sebidang tanah kepada $\mathrm{Ny}$. Pujohartono terletak di dusun Kutu Patran 
RT 05/14 Sinduadi Mlati Sleman Yogyakarta dengan keterangan Sertipikat Hak Milik No. 1625/Desa Sinduadi seluas $1.022 \mathrm{~m} 2$ tanggal 27-8-1990. Gambar Situasi tanggal 16-8-1990 No. 11.779, luas: $1.022 \mathrm{~m} 2$, terakhir atas nama Agus Suharmanto. Sebagaimana alas hak Akta Bagi WarisNo. 215/WR/MLT/1989, Gambar Situasi No. 6047/1989. Ny. Pujohartono telah menjual tanah warisan trsebut kepada Priyoutomo dengan Akta Jual Beli No. 180/2002. Hingga kemudian Priyoutomo mengalihkan tanah tersebut kepada Agus Suharmanto melalui pewarisan;

f. Gambar situasi pada 2 (dua) sertifikat hak atas tanah tersebut ternyata tertukar. Pada tanggal 5 Maret 2015 bertempat di Kantor Pertanahan Kabupaten Sleman para penggugat menuju ke bagian Penyelesaian Sengketa Tanah dan bertemu dengan Seksi Mediasi Bp. Priyantonojati, SE. Kemudian para penggugat bersama Bp. Priyantonojati, SE membuka warkah dan data-data guna membuktikan informasi dari para penggugat mengenai tertukarnya Gambar Situasi kedua sertifikat tanah tersebut. Atas penjelasan Bp. Priyantonojati, selisih data Gambar Situasi pada objek gugatan mengacu pada batas-batas yang tertera pada Akta Bagi Waris. Atas penemuan ini bp. Priyantonojati mengarahkan untuk mengadakan mediasi guna memperbaiki kekeliruan tersebut secara kekeluargaan dibantu BPN Sleman Pada mediasi tersebut pihak Agus Suharmanto tidak hadir tanpa keterangan apapun;

g. Menimbang serta melihat proses dan usaha penyelesaian di luar mekanisme hukum (non litigasi) melalui musyawarah dan mediasi tidak ditanggapi dengan baik oleh Sdr Agus Suharmanto kemudian para penggugat pada tanggal 27 Maret mengajukan gugatan ke PTUN Yogyakarta dengan objek sengketa adalah 2 (dua) sertifikat tanah yang gambar situasinya telah tertukar;

h. Penggugat menyatakan bahwa tindakan tergugat melanggar peraturan perundangan yang berlaku dan melanggar asas kepastian hukum, asas tertib penyelenggaraan negara, dan asas akuntabilitas sehingga menimbulkan cacat administrasi.

5. Sengketa antara PT Neo Husada Sejahtera melawan Kepala Dinas Pekerjaan Umum dan Perumahan Kabupaten Sleman

Objek sengketa dalam kasus ini adalah Surat Kepala Dinas Pekerjaan Umum dan Perumahan Kabupaten Sleman No. 640/1437/2015 tanggal 6 Mei 2015 Perihal Opname Bangunan yang ditujukan kepada Direktur Reserse Kriminal Umum-Kasubdit II/HARDA Polda DIY di Yogyakarta. Dalil gugatan Penggugat adalah sebagai berikut:

1) bahwa antara Penggugat dan Sdr Ricky Yonathan yang beralamat di Kabupaten Sleman dan mengaku sebagai direktur CV Graha Kreasindo mengadakan kerja sama pelaksana pekerjaan pembangunan Hotel Neo Medan dengan Surat Perjanjian No. 001/NHS- ADM/SP4/II/2014 dan Surat Perintah Kerja No. 002/NHSADM/SPK/II/2014 tanggal 10 Februari 2014 sebagai pelaksana pembangunan Neo Aston Medan yang terletak di Jl. Kapt. Patimura No 442, Kelurahan Darat, Kecamatan Medan Baru, Kota Medan;

2) Bahwa dalam melaksanakan pembangunan hotel Sdr Ricky melakukan 
penyimpangan- penyimpangan bahkan patut diduga telah melakukan penipuan ataupun penggelapan yang mengakibatkan pembangunan hotel terhenti sehingga pihak penggugat melaporkan Sdr Ricky ke Polda DIY;

3) Polda DIY setelah mendengarkan para saksi dan mengumpulkan bukti-bukti meminta Tergugat selaku Kepala Dinas Pekerjaan Umum dan Perumahan Kabupaten Sleman untuk melakukan opname bangunan Hotel Neo Medan;

4) Pada saat menjalani pemeriksaan sebagai saksi pihak penggugat mendengar bahwa pihak Tergugat selaku Kepala Dinas Pekerjaan Umum dan Perumahan Kabupaten Sleman telah menerbitkan Surat Kepala Dinas Pekerjaan Umum dan Perumahan Kabupaten Sleman No. 640/1437/2015 tanggal 6 Mei 2015 Perihal Opname Bangunan yang ditujukan kepada Direktur Reserse Kriminal Umum-Kasubdit II/HARDA Polda DIY di Yogyakarta, sehingga atas informasi tersebut pihak penggugat merasa dirugikan kepentingannya baik secara materiil maupun formil. Kemudian Penggugat mengajukan gugatan ke PTUN mengenai terbitnya Surat Kepala Dinas Pekerjaan Umum dan Perumahan Kabupaten Sleman No. 640/1437/2015 tanggal 6 Mei 2015 Perihal Opname Bangunan yang ditujukan kepada Direktur Reserse Kriminal UmumKasubdit II/HARDA Polda DIY di Yogyakarta.

5) Menurut pihak penggugat, tindakan tergugat dengan mengeluarkan Surat Keputusan yang disengketakan bukan merupakan kewenangan pihak tergugat karena bangunan tersebut dibangun secara individual dan tidak menggunakan anggaran pemerintah sehingga pelaksanaan pekerjaan dilakukan berdasarkan perjanjian yang telah disepakati dengan Sdr Ricky. Di samping itu Medan bukan wilayah kerja dari Tergugat. Oleh karena itu pihak penggugat karena merasa dirugikan menuntut agar Surat Kepala Dinas Pekerjaan Umum dan Perumahan Kabupaten Sleman No. 640/1437/2015 tanggal 6 Mei 2015 Perihal Opname Bangunan yang ditujukan kepada Direktur Reserse Kriminal UmumKasubdit II/HARDA Polda DIY di Yogyakarta untuk dicabut.

Pihak penggugat mendalilkan bahwa tindakan tergugat bertentangan dengan asas-asas umum pemerintahan yang baik yaitu asas kepastian hukum dan asas bertindak cermat serta melanggar peraturan perundangundangan yang berlaku dan juga melanggar asas kepatutan. Menurut penggugat objek sengketa yang diterbitkan tergugat patut diduga akan digunakan oleh Sdr Ricky selaku pelaksana pembangunan Hotel Neo Medan sebagai alat bukti dalam kasus pidana dan kasus perdatanya. Setelah memeriksa saksi-saksi dan barang bukti yang diajukan oleh para pihak, PTUN Yogyakarta dalam amar putusannya tanggal 17 Desember 2015 mengabulkan tuntutan pihak penggugat pada saat ini putusan hakim PTUN Yogyakarta tersebut telah mempunyai kekuatan hukum yang tetap.

Putusan Hakim PTUN Yogyakarta Terhadap Pelanggaran AUPB Setelah Berlakunya UU Administrasi Pemerintahan

Setelah dicermati dan dianalisis, dari lima kasus gugatan yang telah diputuskan oleh hakim PTUN Yogyakarta yang telah mempunyai kekuatan hukum yang tetap 
(inkrah) tersebut, maka ditemukan faktafakta mengenai putusan hakim tersebut sebagai berikut: sebagai berikut:

\section{Kasus PT Pertamina Training And Consulting Jakarta melawan Tergugat Pihak Pegawai Pengawas Ketenagakerjaan Dinas Tenaga Kerja dan Transmigrasi Kabupaten Bantul}

Putusan hakim dalam sengketa ini menyatakan bahwa gugatan penggugat tidak diterima dengan dasar pertimbangan di antaranya adalah sebagai berikut:

a. Ada pihak ketiga yang terkait dengan objek sengketa, sehingga hakim PTUN Yogyakarta dengan berpedoman pada ketentuan Pasal 83 UU No. 5 Tahun 1986 tentang Peradilan Tata Usaha Negara telah memanggil pihak ketiga yakni Awak Mobil Tangki (AMT)untuk dimintai keterangan dan diberikan penjelasan mengenai hak-hak dan kewajiban-kewajibannya sebagai pihak intervensi dalam sengketa tersebut. Namun demikian pihak ketiga tersebut setelah dipanggil dengan patut tidak pernah hadir di persidangan. Ada AMT yang datang di persidangan (Agus Suparjiyo dan Kardiyono) namun tidak menyatakan akan masuk sebagai pihak ketiga dalam persidangan. Dengan demikian dinilai telah melepaskan hak hukumnya untuk membela kepentingannya;

b. Seharusnya sesuai dengan peraturan perundangan yang berlaku terkait dengan hubungan industrial yang tercantum dalam Pasal 13 Keputusan Menteri Tenaga Kerja dan Transmigrasi seharusnya penggugat menempuh dulu upaya banding administrasi, sehingga sesuai dengan ketentuan Pasal 62 UU Peradilan Tata Usaha Negara maka sudah selayaknya apabila gugatan penggugat dinyatakan "tidak diterima";

c. Menurut pertimbangan dan penilaian hakim objek sengketa bukan merupakan kewenangan absolut dari PTUN Yogyakarta, sehingga harus diselesaikan dulu melalui upaya administratif walaupun objek sengketa sudah memenuhi unsur Keputusan Tata Usaha Negara sebagaimana tertuang dalam ketentuan Pasal 1 angka (9) UUNo. 51 Tahun 2009 tentang Perubahan Kedua Atas UU No. 5 Tahun 1986 tentang Peradilan Tata Usaha Negara

\section{Kasus I Nyoman Tri Santoso SIP melawan Kepala Kantor Pertanahan Kabupaten Sleman}

Gugatan Penggugat ini tidak diterima oleh majelis hakim dengan alasan sebagai berikut:

a. Gugatan penggugat sudah kedaluwarsa

b. Gugatan kabur atau tidak jelas; berdasarkan keterangan saksi-saksi telah terjadi proses jual beli tanah antara istri I Nyoman Santosa dengan Sdr Ikhsan yang dinyatakan DPO yang tidak pernah datang sewaktu dipanggil di persidangan PTUN Yogyakarta walaupun telah dipanggil secara patut. Majelis hakim dalam pertimbangannya juga mendalilkan pendapat dari para ahli seperti Indroharto dalam bukunya "Usaha Memahami UU tentang Peradilan Tata usaha Negara" Penerbit Sinar Harapan, Jakarta, tahun 1993 halaman 37 sampai dengan halaman 40 mengenai pengertian kepentingan dalam kaitannya dengan Hukum Tata Usaha Negara yang menunjuk kepada nilai yang harus dilindungi oleh hukum dan kepentingan proses, artinya apa yang hendak dicapai dengan melakukan suatu proses gugatan yang bersangkutan di samping itu mejelis 
hakim juga merujuk pada pendapat Hadjon (1995, p. 324) yang pada pokoknya menyebutkan bahwa penggugat (seseorang atau badan hukum perdata) mempunyai kepentingan menggugat (hak gugat), apabila ada hubungan kausal langsung antara Keputusan Tata Usaha Negara yang digugat dengan kerugian atau kepentingannya;

c. Hakim mempertimbangkan bahwa dalam hukum acara Peradilan Tata Usaha Negara tidak tertulis ada adagium "Point d'interetst-Point d'action" yang artinya bila ada kepentingan, maka di situ baru boleh mengajukan gugatan/berproses. Oleh karena telah terjadi peralihan hak atas tanah dari I Nyoman Santosa yang berdasarka keterangan saksi Notaris Endang SumarnisngsihSH, Mkn, notaris di Sleman ke sdr Ikhsan dengan akta jual beli yang dilakukan proses jual beli antara istri penggugat (I Nyoman Santosa) dengan sdr Ikhsan maka majelis hakim menilai tidak ada kepentingan langsung atau tidak ada hubungan kausal langsung antara penggugat dengan sertifikat Hak Milik yang dikeluarkan tergugat atas nama Ikhsan. Hal ini juga merupakan alasan majelis hakim menolak gugatan Penggugat.

Setelah dianalisis sebetulnya kasus ini juga berkaitan dengan kasus pidana dan perdata. Menurut pertimbangan hakim ranah persoalan ini juga bukan merupakan kompetensi absolut dari PTUN Yogyakarta, dan gugatan telah lewat waktu (kedaluarsa) sehingga gugatan penggugat ke PTUN Yogyakarta tidak diterima oleh majelis hakim. Menurut penilaian hakim tidak ada pelanggaran peraturan perundangan yang berlaku dari sisi Hukum administrasi Negara terhadap tindakan yang dilakukan oleh tergugat Kepala Kantor Pertanahan Kabupaten Sleman. Tindakan pelanggaran terhadap asas-asas umum pemerintahan yang baik yakni asas kepastian hukum, proporsionalitas dan profesionalitas menurut penilaian hakim juga tidak terbukti dalam sikap diam pihak tergugat.

3. Kasus Yundarningsih. SN, SPd melawan Kepala Kantor Regional I BKN Yogyakarta

Kasus ini merupakan kasus sengketa kepegawaian yang dimenangkan oleh pihak penggugat. Dalam putusan PTUN Yogyakarta yang telah mempunyai kekuatan hukum yang tetap dimenangkan oleh pihak penggugat dengan alasan bahwa pihak tergugat melanggar peraturan perundangundangan yang berlaku dan melanggar asasasas umum pemerintahan yang baik. Namun demikian dalam putusan pengadilan tidak dirinci dan disebutkan asas-asas umum pemerintahan yang baik apa saja yang dilanggar oleh pihak tergugat.

Gugatan tersebut setelah diperiksa dan diadakan penilaian serta diadili oleh majelis hakim PTUN Yogyakarta setelah mempertimbangkan bukti-bkti dan saksisaksi yang diajukan kedua belah pihak akhirnya dikabulkan oleh PTUN Yogyakarta dengan menyatakan mengabulkan gugatan penggugat untuk seluruhnya dan menyatakan batal Surat Keputusan Kepala Kantor Regional I Badan Kepegawaian Negara Nomor 000166/KEP/BV/23316 tertanggal 28 Oktober 2014 mengenai Pensiun atas nama Yundarningsih, SN. SPd serta memerintahkan tergugat untuk menerbitkan Surat Keputusan Baru berupa Surat Keputusan Pemberhentian dengan hormat sebagai PNS dengan hak pensiun pada bulan Januari 2015 dan Pensiun mulai terhitung tanggal 1 Februari 2015.

Putusan PTUN Yogyakarta dalam sidang tanggal 27 Mei 2015 yang telah mempunyai kekuatan hukum yang tetap memenangkan penggugat dengan alasan bahwa tergugat melanggar peraturan perundang-undangan yang berlaku dan melanggar asas- asas umum pemerintahan yang baik. Namun demikian 
dalam putusan majelis hakim PTUN Yogyakarta tidak disebutkan secara rinci asas-asas apa saja yang dilanggar oleh pihak tergugat. Dalam amar putusan hakim menyatakan bahwa:

a. Eksepsi pihak tergugat tidak dapat diterima;

b. Mengabulkan gugatan penggugat untuk seluruhnya;

c. Menyatakan batal Surat Keputusan Tergugat Kepala Kantor Regional I Badan Kepegawaian Negara Nomor 000166/KEP/BV/23316 tertanggal 28 Oktober 2014 mengenai Pensiun atas nama Yundarningsih, SN. SPd;

d. Memerintahkan Tergugat untuk untuk mencabut Surat Keputusan Nomor 000166/KEP/BV/23316 tertanggal 28 Oktober 2014 mengenai Pensiun atas nama Yundarningsih, SN. SPd;

e. Memerintahkan Tergugat untuk untuk menerbitkan Surat Keputusan baru berupa Surat Keputusan Pemberhentian dengan Hormat sebagai PNS dengan hak Pensiun, yang memberhentikan penggugat akhir bulan Januari 2015 dan Pensiun terhitung tanggal 1 Februari 2015;

f. Memerintahkan Tergugat untuk merehabilitasi hak-hak Penggugat seperti semula sebelum terbitnya objek sengketa hingga diterbitkannya Surat Keputusan baru sesuai dengan ketentuan peraturan perundang-undangan yang berlaku.

4. Kasus Ny. Suwalini Soegito dkk. melawan Kepala Kantor Pertanahan Kabupaten Sleman sebagai Tergugat Majelis hakim PTUN Yogyakarta menolak gugatan para penggugat dengan alasan pokok sengketa atau pokok perkara bukan merupakan kewenangan absolut PTUN Yogyakarta karena merupakan wilayah hukum privat atau perdata (hak-hak perdata atau privat). Adapun dasar pertimbangan hukum hakim dalam menjatuhkan putusan adalah sebagai berikut:

a. Objek sengketa yang dimohonkan untuk dinyatakan batal atau tidak sah adalah:
1) Sertifikat Hak Milik No. 1622/ Desa Sinduadi, tanggal 27-8-1990, Gambar situasi tanggal 16-8-1990 No. 11.776 luas: $1.199 \mathrm{~m} 2$, terakhir atas nama Hadi Sugito;

2) Sertifikat Hak Milik no. 1625/ Desa Sinduadi, tanggal 27-8-1990, Gambar situasi tanggal 16-8-1990 No. 11.779, luas : $1022 \mathrm{~m} 2$, terakhir atas nama Agus Suharmanto.

b. Bahwa objek sengketa berkaitan dengan pihak ketiga yakni Agus Sudarmanto yang telah dipanggil secara patut untuk dimintai keterangan dan diberi penjelasan mengenai hak dan kewajibankewajibannya untuk masuk sebagai pihak intervensi namun tidak pernah hadir;

c. Untuk itu majelis hakim menilai bahwa pihak (Agus Sudarmanto) telah melepaskan hak hukumnya untuk membela kepentingannya;

d. Dalam rangka mencari kebenaran materiil majelis hakim telah meminta keterangan Agus Sudarmanto sebagai saksi dan telah datang di persidangan pada tanggal 4 Agustus 2015;

e. Setelah mendengar keterangan dari para saksi dan bukti-bukti dalam persidangan, majelis hakim berkesimpulan bahwa: ada persoalan pendahuluan di dalam Akta Pembagian Harta Warisan No. 212/WR/MLT//1989 dan Akta Pembagian Harta Warisan No. 215/WR/MLT//1989 yang harus diselesaikan/diberikan kepastian terlebih dahulu sehingga dalam amar putusannya hakim menyatakan menerima eksepsi tergugat dan menyatakan gugatan para penggugat tidak diterima. Alasan pertimbangan hakim dalam melakukan penilaian terhadap penyelesaian sengketa ini adalah karena hal ini merupakan 
sengketa di bidang perdata sehingga bukan merupakan kewenangan absolut dari Peradilan Tata Usaha Negara dalam menyelesaikannya.

Setelah dilakukan analisis memang kasus ini sebetulnya berawal dari kurang cermatnya petugas Kantor Pertanahan Kabupaten Sleman dalam menerbitkan Sertifikat Hak Milik Atas Tanah sewaktu orang tua para Penggugat mengurus Sertifikat Hak Milik atas Tanah yang kemudian menimbulkan sengketa dalam bidang keperdataan yang sulit didamaikan. Oleh karena itu seharusnya kasus perdatanya harus diselesaikan terlebih dahulu baru.

5. Kasus PT Neo Husada Sejahtera selaku Penggugat melawan Kepala Dinas Pekerjaan Umum dan Perumahan Kabupaten Sleman sebagai Tergugat

Kasus ini awalnya merupakan kasus perdata dan kasus pidana yang akhirnya merembet ke kasus sengketa tata usaha negara akibat dari dikeluarkannya Surat Kepala Dinas Pekerjaan Umum dan Perumahan Kabupaten Sleman No. 640/1437/2015 tanggal 6 Mei 2015 Perihal Opname Bangunan yang ditujukan kepada Direktur Reserse Kriminal Umum-Kasubdit II/HARDA Polda DIY di Yogyakarta. Surat Keputusan tersebut dikeluarkan oleh Kepala Dinas Pekerjaan Umum dan Perumahan Kabupaten Sleman atas perintah dari Polda DIY terhadap kasus pidana Sdr Ricky. Namun demikian karena Surat Keputusan tersebut merugikan pihak penggugat maka kemudian digugat melalui PTUN Yogyakarta.

Setelah memeriksa saksi-saksi dan barang bukti yang diajukan oleh para pihak, majelis hakim PTUN Yogyakarta dalam amar putusannya tanggal 17 Desember 2015 mengabulkan tuntutan pihak penggugat. Pada saat ini putusan hakim PTUN Yogyakarta tersebut telah mempunyai kekuatan hukum yang tetap (inkraf). Dalam amar putusannya hakim PTUN Yogyakarta menyatakan bahwa:

a. Eksepsi tergugat tidak diterima untuk seluruhnya;

b. Mengabulkan gugatan penggugat seluruhnya;

c. Menyatakan tidak sah Keputusan Tata Usaha Negara yang berupa Surat Kepala Dinas Pekerjaan Umum dan Perumahan Kabupaten Sleman No. 640/1437/2015 tanggal 6 Mei 2015 Perihal Opname Bangunan yang ditujukan kepada Direktur Reserse Kriminal UmumKasubdit II/HARDA Polda DIY di Yogyakarta;

d. Memerintahkan tergugat untuk mencabut Surat Kepala Dinas Pekerjaan Umum dan Perumahan Kabupaten Sleman No. 640/1437/2015 tanggal 6 Mei 2015 Perihal Opname Bangunan yang ditujukan kepada Direktur Reserse Kriminal Umum- Kasubdit II/HARDA Polda DIY di Yogyakarta,;

e. Memerintahkan pihak tergugat untuk membayar biaya perkara.

Setelah dianalisis, putusan hakim mengabulkan gugatan penggugat karena tindakan tergugat dinilai oleh hakim melanggar peraturan perundang-undangan yang berlaku. Di samping itu tindakan tergugat juga melanggar asas-asas umum pemerintahan yang baik yakni asas kepastian hukum dan asas bertindak cermat.

Berdasarkan analisis, setelah melihat putusan-putusan hakim PTUN Yogyakarta dengan memperhatikan asas-asas umum pemerintahan yang baik sebagaimana tertuang dalam Pasal 10 UU Administrasi Pemerintahan maka dapat dikemukakan bahwa putusan hakim PTUN Yogyakarta 
sudah tidak lagi mengacu pada ketentuan Pasal 3 UU No. 28 Tahun 1999 yang menyatakan bahwa asas-asas umum pemerintahan yang baik yakni asas: kepastian hukum; tertib penyelenggaraan negara; keterbukaan; proporsionalitas; profesionalitas; akuntabilitas. Hal ini terbukti bahwa dalam mengabulkan gugatan sengketa antara PT Neo Husada Sejahtera selaku Penggugat melawan Kepala Dinas Pekerjaan Umum dan Perumahan Kabupaten Sleman sebagai Tergugat mendasarkan diri bahwa keputusan yang digugat oleh pihak penggugat di samping melanggar ketentuan peraturan perundang-undangan yang berlaku juga melanggar asas kepastian hukum dan asas bertindak cermat. Sedangkan dalam putusan sengketa antara Yundarningsih SN SPd, gugatan penggugat serta penilaian hakim tidak menyebutkan secara rinci asas-asas umum pemerintahan yang baik yang telah dilanggar oleh tergugat.

Hal tersebut sesuai dengan keterangan salah seorang hakim PTUN Yogyakarta yang menyatakan bahwa putusan hakim di samping mengacu pada peraturan perundangundangan yang berlaku juga mendasarkan diri pada pendapat para ahli terutama ahli Hukum Administrasi Negara. Berdasarkan ketentuan Pasal 10 ayat (1) dan ayat (2) UU Administrasi Pemerintahan asas-asas umum pemerintahan yang baik yang tertuang dalam putusan hakim yang telah mempunyai kekuatan hukum yang tetap diakui selain asas-asas umum pemerintahan yang baik sebagaimana tertuang dalam ketentuan Pasal 10 ayat (1) UU Administrasi Pemerintahan yakni asas: kepastian hukum; kemanfaatan, ketidakberpihakan; kecermatan; tidak menyalahgunakan kewenangan; keterbukaan; kepentingan umum; dan pelayanan yang baik.

\section{Simpulan}

Berdasarkan uraian-uraian pada bab-bab terdahulu dapat dikemukakan simpulan sebagai berikut:

Pertama, ditemukan lima (5) kasus gugatan sengketa tata usaha negara yang telah diputuskan secara inkrah oleh hakim PTUN Yogyakarta dalam penelitian ini. Lima

(5) kasus tersebut yakni:

1. Sengketa antara PT Pertamina Training And Counsulting Jakarta selaku pihak penggugat melawan tergugat pihak Pegawai Pengawas Ketenagakerjaan Dinas Tenaga Kerja dan Transmigrasi Kabupaten Bantul;

2. Sengketa antara I Nyoman Tri Santoso SIP selaku penggugat melawan Kepala Kantor Pertanahan Kabupaten Sleman selaku tergugat;

3. Sengketa kepegawaian antara Yundarningsih. SN, SPd melawan Kepala Kantor Regional I Badan Kepegawaian Negara selaku tergugat yang berkedudukan di Jl Raya Magelang Km 7,5 Sleman Yogyakarta;

4. Sengketa antara Ny. Suwalini Soegito dkk sebagai penggugat melawan Kepala Kantor Pertanahan Kabupaten Sleman sebagai tergugat; dan

5. Sengketa antara PT Neo Husada Sejahtera selaku penggugat melawan Kepala Dinas Pekerjaan Umum dan Perumahan Kabupaten Sleman sebagai tergugat.

Kedua, Putusan hakim PTUN Yogyakarta memperlihatkan bahwa dari lima sengketa tata usaha negara dua (2) kasus di antaranya, dimenangkan oleh pihak penggugat. Asas yang dilanggar yakni asas kepastian hukum dan asas bertindak cermat dalam kasus sengketa antara PT Neo Husada sejahtera melawan Kepala Dinas Pekerjaan Umum dan Perumahan Kabupaten Sleman 
selaku tergugat. Dalam kasus sengketa Yundarningsih SN SPd tidak disebutkan secara rinci asas-asas umum pemerintahan yang baik yang dilanggar tergugat dalam putusan hakim PTUN Yogyakarta. Tiga (3) kasus dimenangkan oleh pihak tergugat dengan alasan penilaian hakim bahwa tindakan tergugat tidak melanggar peraturan perundang-undangan yang berlaku dan asasasas umum pemerintahan yang baik. Selain itu juga menurut penilaian hakim sengketa yang diajukan penggugat bukan merupakan kewenangan absolut dari Peradilan Tata Usaha Negara melainkan merupakan kewenangan dari peradilan lain melawan Kepala Kantor Regional I Kepegawaian Negara.

Setelah melihat uraian hasil penelitian dan pembahasan yang telah dipaparkan pada bab terdahulu maka dikemukakan saran-saran sebagai berikut:

1. Melihat fakta bahwa dari lima (5) gugatan para penggugat dalam sengketa kepegawaian yang diajukan ke PTUN Yogyakarta seringkali berkaitan dengan kasus pidana dan perdata yang sudah terjadi lebih dahulu, sebaiknya penyelesaian sengketa dibawa ke ranah peradilan umum dalam penyelesaiannya. Hal ini mengingat bahwa kewenangan absolut hakim peradilan tata usaha negara hanyalah menyelesaikan sengketa tata usaha negara;

2. Hakim PTUN Yogyakarta hendaknya di dalam menyelesaikan sengketa tata usaha negara akibat adanya pelanggaran asasasas umum pemerintahan yang baik, sedapat mungkin mengacu pada ketentuan
Pasal 10 ayat (1) dan (2) Undang-Undang Administrasi Pemerintahan;

3. Badan atau Pejabat Tata Usaha Negara seyogyanya di dalam mengeluarkan Keputusan Tata Usaha Negara mendasarkan diri pada perundangundangan yang berlaku dan asas-asas umum pemerintahan yang baik sebagaimana diatur dalam ketentuan Pasal 10 ayat (1) dan (2) Undang-Undang Administrasi Pemerintahan.

\section{Daftar Pustaka}

Hadjon, P. M. (1995). Pengantar Hukum Administrasi Indonesia. Yogyakarta: Gadjah Mada University Press.

Marbun, S. (2003). Peradilan administrasi negara dan upaya administratif di Indonesia. Yogyakarta: FH UII Press.

Purbopranoto, K. (1978). Beberapa catatan hukum tata pemerintahan dan peradilan administrasi negara. Bandung: Alumni.

Wiyono, R. (2005). Hukum acara peradilan tata usaha negara. Jakarta: Sinar Grafika.

Undang-Undang Republik Indonesia No. 28 Tahun 1999 tentang Penyelenggaraan Negara yang Bersih dan Bebas dari KKN.

Undang-Undang Republik Indonesia No. 5 Tahun 1986 tentang Peradilan Tata Usaha Negara.

Undang-Undang Republik Indonesia No. 9 Tahun 2004 tentang Perubahan Atas No. 5 Tahun 1986 tentang Peradilan Tata Usaha Negara.

Undang-Undang Republik Indonesia No. 51 Tahun 2009 tentang Perubahan Kedua Atas No. 5 Tahun 1986 tentang Peradilan Tata Usaha Negara.

Undang-Undang Nomor 30 Tahun 2014 tentang Administrasi Pemerintahan 